\title{
POTENSI RADIKAL-TERORISME DALAM PAHAM TEOLOGI SALAFIYAH: STUDI KASUS TERHADAP YAYASAN MINHAJ AS-SUNNAH MEDAN, SUMATERA UTARA
}

\author{
Adenan* \& Husnel Anwar Matondang
}

Fakultas Ushuluddin dan Studi Islam - Universitas Islam Negeri Sumatera Utara, Medan

\begin{tabular}{|c|c|}
\hline Article History & Abstrak \\
\hline Received : January, 2019 & \multirow{5}{*}{$\begin{array}{l}\text { Artikel ini bertujuan untuk menjawab kecurigaan sebagian anggota } \\
\text { masyarakat terhadap Salafiyah secara umum. Salah satu yayasan } \\
\text { berfahan salafi, yaitu Yayasan Minhaj as-Sunnah, dijadikan sebagai objek } \\
\text { penelitian. Fokus masalahnya adalah apa yang melatarbelakangi Yayasan } \\
\text { Minhaj As-Sunnah menjadikan Salafiyah sebagai dasar teologis } \\
\text { keagamaannya dihubungkan dengan pemahaman radikalisme- } \\
\text { terorisme. Hasil temuan dari penelitian ini adalah Manhaj Salafiyah } \\
\text { menggunakan metodologi penafsiran teks Al-Quran dan Sunnah yang } \\
\text { disusun para salaf untuk membentengi Islam dari penafsiran-penafsiran } \\
\text { keliru dan menyesatkan yang didasari oleh kepentingan hawa nafsu. } \\
\text { Yayasan Minhaj As-Sunnah memahami bahwa Manhaj Salafiyah tidak } \\
\text { memiliki hubungan dengan gerakan dan pemahaman radikal-terorisme. }\end{array}$} \\
\hline Accepted : January, 2019 & \\
\hline Published : February, 2019 & \\
\hline Kata Kunci & \\
\hline $\begin{array}{l}\text { Salafiyah, Minhaj As-Sunnah, } \\
\text { radikalisme, terorisme. }\end{array}$ & \\
\hline
\end{tabular}

\section{PENDAHULUAN}

Tidak sedikit klaim yang menempatkan Salafiyah atau Salafi sebagai gerakan radikalisme. Di dalam sejumlah blog ditemukan pendapat yang menghubungkan terorisme dengan Salafisme. Sebuah artikel ditulis dengan judul yang sangat ensure, "Terorisme Pasti Berakidah Wahabi Salafi" ${ }^{2}$ dan sejumlah video di YouTube terkait "Salafi Wahabi Bukan Ahli Sunnah, Akar Terorisme Dunia". Dalam artikel lainnya, dikemukakan pula ungkapan dengan nada tuduhan bahwa Salafi menciptakan permusuhan dan bibit terorisme. ${ }^{2}$ Fenomena blasphemy terhadap Salafisme tersebut menjadi sesuatu yang massif disuarakan sebagian kelompok masyarakat di Indonesia yang mengundang perhatian.

Tuduhan terhadap Salafiyah didukung oleh konsep keimanan yang mereka anut. Iman dipahami kelompok ini sebagai perkataan (al-qaul) dan perbuatan (al'amal). ${ }^{3}$ Konsep ini dapat dijadikan dasar untuk mengkalim kelompok yang tidak mengamalkan syariat atau tidak menjadikan syariat Islam sebagai ideologi negara memungkinkan diklasifikasikan ke dalam kekafiran, tidak beriman, atau murtad. Demikian juga dengan konsep "Islam Kaffah" yang menjadi kerangka keagamaan paham Salafisme ditengarai dapat menghantarkan pada paham radikal-terorisme. Idealisme paham teologis kelompok ini tentunya akan berseberangan dengan nilai-nilai sosial yang ada di Sumatera Utara, bahkan di Indonesia.

Keberadaan Minhaj Salafi di Sumatera Utara telah berkembang sejak sepuluh tahun terakhir. Jamaah ini tidak mengasosiasikan diri ke dalam suatu organisasi Salafisme, tidak seperti Muhammadiyah, Al-Washliyah, dan Nahdhatul Ulama. Kenyataan ini mengindikasikan Salafisme merupakan manhaj atau mazhab pemikiran 
bukan organisasi masyarakat. Karena itu, jumlah pengikut jamaah Salafi sukar untuk diketahui secara konkrit.

Pada umumnya, jamaah Salafi dikembangkan di Sumatera Utara melalui majelismajelis pengajian, seperti di masjid, kampus, kantor, sekolah, dan rumah-rumah penduduk. Perkembangan kuantitas jamaah ini juga dimungkinkan oleh bias dari sosial media, internet, TV, radio, buku, jurnal, buletin, dan lembaga-lembaga dakwah. Salah satu lembaga yang berkomitmen memasyarakatkan Minhaj Salafi di Sumatera Utara adalah Minhaj as-Sunnah. Lembaga ini berbentuk yayasan yang bergerak di bidang pendidikan dan dakwah. Yayasan tersebut berada jalan Karya Jaya Gang Ekawali Pribadi, Gedung Johor, Medan Johor, Kota Medan, Sumatera Utara, kode Pos 20144, Indonesia.

Dalam pengamatan awal, pengajian-pengajian yang dilakukan oleh yayasan ini tidak melakukan doktrinasi kepada jamaahnya untuk bersikap ekstrim, radikal, dan mendukung paham terorisme. Justru sebaliknya, para asatiz yang menyampaikan ceramah melarang berperilaku ekstrim (ghuluw) dalam beragama. Ditemukan juga penegasan dari sejumlah asatiz yang mengharamkan terorisme bagi kaum muslim. ${ }^{4}$ Karena itu, apa yang selama ini dinisbatkan kepada Salafisme secara negatif yang merupakan minhaj yayasan ini sangat bertentangan dengan anggapan, komentar, dan tulisan yang menempatkan Manhaj Salaf sebagai aliran radikal-terorisme.

Penjajakan awal terhadap jamaah yayasan Minhaj as-Sunnah tidaklah diinferensikan telah merefresentasikan seluruh paham teologinya. Untuk mengetahui keberadaan paham teologi tersebut haruslah melihat konstruksi bangunan teologinya secara mendalam, mualai dari konsep akidah, syariah, dan akhlak. Guna mengetahui secara mendalam dan objektif, maka diperlukan suatu penelitian ilmiah terhadap yayasan ini. Atas tujuan inilah maka dilakukan studi kasus terhadap salah satu lembaga yang paling aktif menyuaran Manhaj Salaf di Sumatera Utara.

\section{HASIL DAN PEMBAHASAN}

\section{Embrio dan Pertumbuhan Paham Salafi di Nusantara}

Menurut beberapa teori seperti dari sumber Cina klasik, Kitab Nukhbah al-Dahri, dan The Preaching of Islam dikemukakan bahwa Islam pertama sekali masuk ke Indonesia pada abad pertama Hijriyah. Berlandaskan teori ini maka dapat dikemukakan bahwa Islam pertama masuk ke Nusantara adalah Islam yang berpaham Salaf. Pada era itu, belum ditemukan paham-paham lain yang berkembang di dunia Arab kecuali paham Salaf itu sendiri (Azra, 2013, pp. 20-21).

Secara perlahan Islam terus tumbuh, namun Islam baru berkembang di Nusantara beberapa ratus tahun berikutnya, khususnya abad ke-13 M (Zahir, 2001, pp. 104-127). Pada umumnya mayoritas didominasi oleh Islam yang dipengaruhi sufisme (Azra, 2013, p. 15). Ternyata Islam versi sufisme ini mendapat sambutan yang baik dari penduduk Nusantara, hal itu dibuktikan dengan pesatnya penduduk Nusantara masuk Islam dan munculnya kerajaan-kerajaan Islam di bebarapa wilayah yang sekarang menjadi Indonesia. Perkembangan pesat terjadi di Sumatera, Jawa, dan pulau-pulau lainnya. Wali Songo menjadi kata kunci tersiarnya Islam di Jawa. Sikap kompromi dan gradualisasi penerapan ajaran Islam, termasuk akidah, yang diterapkan sebagian dari Wali Songo yang berhasil mengislamisasikan tanah Jawa pada tataran identitas 
keagamaan penduduk. Kendatipun demikian, sebagian wali tidak menyetujui pola dakwah yang melegitimasi (hiresi ?) teologis dalam tahapan dakwah tersebut. Karena itulah di Jawa perpaduan ajaran Hindu dan Islam masih terus berlangsung, terutama kelompok priyai dan abangan - jika mengikut teori pembagian masyarakat Jawa oleh Geertz - sementara priayi adalah kaum yang secara umum telah mendalami Islam Kaffah.

Setelah beberapa abad, pemahaman Salaf mengalami revitalisasi oleh kelompok pembaharu di Arabia. Ajaran Salafi tersebut lambat laun merasuk secara perlahan ke berbagai wilayah seperti Mesir dan termasuk juga Nusantara. Gerakan ini muncul dan berkembang di Indonesia sejak era kolonial Belanda. Salah satunya yang mencuat adalah Gerakan Paderi yang dipelopori oleh Tuanku Nan Tuo, orang Paderi dari Koto Tuo Ampek Anggek Candung 1784-1803 (Tholhah, 2003, p. 35). Muncul nama lainnya seperti Haji Miskin, Haji Piobang, dan Imam Bonjol yang menjadi penggagas pemurnian Islam di Minangkabau. Dalam transmisi ini, ditemukan juga peran seorang reformis yang datang dari negeri Sudan pada bulan Rabiul Awwal 1329 H., ia adalah Ahmad bin Muhammad as-Surkati. Namun demikian, seperti yang dikatakan Abdurrahman bin Abdul Karim at-Tamimi tokoh ini tidaklah diklaim sebagai Salaf yang utuh, 5 akan tetapi ia telah berhasil turut serta membangun fondasi Salafisme yang muncul berikutnya.

Dalam ranah transmisi ini juga tidak dapat dikecilkan peran Syarekat Islam, Muhammadiyah, Persis, dan al-Irsyad. Tokoh-tokoh oraganisasi ini, seperti KH. Ahmad Dahlan, A. Hasan, dan lainnya, turut mengambil bagian dari usaha memasukkan ajaranajaran Salafisme ke Nusantara. Namun, sebagaimana Ahmad as-Surkati, tokoh-tokoh ini juga tidak dapat dimasukkan ke dalam Salafisme utuh. Selain itu, mereka juga tidak menisbatkan diri sebagai Salafi sebagaimana orang-orang Salafi belakangan.

Momentum Salafi babak ke-3 di Indonesia muncul sekitar tahun 1980-an dan terus menguat pada 1990-an hingga melejit pada awal abad ke-21 ini. Secara faktual, kebangkitan ini muncul karena dipengaruhi oleh banyak peristiwa, namun peran LIPIA (Lembaga Ilmu Pengetahuan Islam dan Arab) di Jakarta yang awalnya bernama LPBA (Lembaga Pengajaran Bahasa Arab). Lembaga ini merupakan cabang dari King Saud University di Riyadh. Para alumni ini banyak yang melanjutkan studi ke Arab Saudi atas beasiswa pemerintah Arab Saudi. Lembaga tersebut melahirkan orang-orang seperti Abu Nida, Ahmad Faiz Asifuddin, Aunur Rafiq Ghufran yang juga merupakan kader DDII (Dewan Dakwah Islamiyah Indonesia) (Hasan, 2008, p. 65), dan sejumlah tokoh yang akan disinggung berikutnya. Setelah kembali ke Indonesia mereka mengajar di pesantren dan kegiatan-kegiatan dakwah. Menurut mereka umat Islam Indonesia butuh pemahaman Islam yang sejati sebagaimana yang dipraktekkan as-Salafash-Shalih yang telah mereka pelajari (Hasan, 2008, p. 65).

Berdasarkan deskripsi di atas, Salafi babak ke-3 ini lebih kental datang dari pengaruh Arab Saudi. Selain Arab Saudi, ajaran Salafi masuk ke Indonesia berasal dari Kuwait dan Yaman. Mereka ini diklaim oleh orang-orang yang tidak sepaham dengan gerakan dakwah purifikasi ini sebagai Wahabi (Wahabisme). Namun oleh orang-orang Salafi, seperti Syaikh Muhammad Jamil Zainu, salah seorang ulama kenamaan di Timur Tengah, menganggap hal ini sebagai apresiasi, dan mereka menisbahkan dengan nama Allah, al-Wahhab. Dalam perjalan waktu, perkembangan dakwah Salafi mendapat dukungan dari tokoh-tokoh Salafi dari negara-negara Arab tersebut. Hal ini ditandai 
dengan kedatangan tokoh-tokoh penting dan ulama dari Arab Saudi, Kuwait, Yaman, Jordania sebagaimana nanti akan dijelaskan.

Di antara tokoh-tokoh sentral Salafi yang mencuat ke permukaan adalah Ja'far Umar Thalib (Yogyakarta), ${ }^{6}$ Abu Nida (Yogyakarta), Abdul Hakim Abdat (Jakarta), Yusuf Usman Baisa, dan Yazid ibn Abdul Qadir Jawas (Bogor, Badrus Salam, Ali Musri (Padang), Ahmad Faiz Asifuddin (Solo), Zain al-Atas (Batam), Hamzah Abas (Bekasi), Djazuli (Bekasi), Ali Salman Hasan (Bekasi), Mudrika Ilyas (Bekasi), Ali Salman Hasan (Jakarta), Arman Amri (Padang), Abu Zuhri (Cileungsi), Pawaz (Cileungsi), Muhammad Umar as-Sawed (Solo), Abu Haidar (Cileungsi), Firdaus Sanusi (Jakarta), Abu Qatadah (Tasik Malaya). Abu Lukman (Jakarta), Zainal Abidin (Cileungsi), Ali Subana (Cileungsi), Abu Ihsan al-Asari (Medan), Ali Nur (Medan), Jamaluddin (Medan), Faisal Jamil (Medan), Ali Ismah (Medan), Abu Umar Basyir (Kalimantan), Zulqarnain (Sulawesi), dan lain-lain.

Tokoh-tokoh salafi di atas telah membagun jaringan Salafiyah. Jaringan intelektual Salafi tersebut dibagun tidak saja antar sesama ustadz Salafi di Nusantara tetapi juga dengan ulama Timur Tengah. Selain belajar ke Saudi dan Yaman, para ustadz Salafi juga menghadirkan Ulama Timur Tengah ke Indonesia seperti Syaikh Ali ibn Hasan, Syaikh Masyhur Hasan Salman, Syaikh Muhammad ibn Muhsin, Syaikh Salim al-Hilali, Syaikh Abd ar-Razzaq, Syaikh Ibrahim ar-Ruhaili, dan lainnya. Di Nusantara juga sering dilakukan daurah dengan menghadirkan ustadz Nusatanra secara bergantian, ustadz Jawa hadir ke Sumatera dan ustadz Sumatera diundang keluar pulau Sumatera dan demikian daerah lainnya di Nusantara, sehingga terjalin jaringan silaturrahmi antar sesama ustadz dan jamaah Salafi. Jaringan ini juga terbentuk dengan Salafi negara tetangga seperti Malaysia.

Di Indonesia juga ditemukan sejumlah pesantren Salafi seperti Pesantren Imam Ahmad Branagsiang, Minhajus Sunnah (Bogor), Ihya' as-Sunnah (Tasikmalaya), alMa'had Bermanhaj Salafi Kabupaten Bekasi (Bekasi), Pesantren Imam al-Bukhari, Pesantren Islam al-Irsyad (Solo), Hidayatun Najah (Bekasi), Pesantren Bin Baz, Ma'had as-Sunnah, dan lainnya. Selain pesantren, ditemukan pula sejumlah Sekolah Dasar, SMP dan SMA, seperti Sekolah Dasar an-Najah, Pesantren al-Turas al-Islami, Islamic Centre Bin Baz (Yogyakarta), Pondok Pesantren As-Sunnah (Cirebon), dan Ulun Nuha di Medan untuk tingkat SMP dan SMU. Selain sekolah sejumlah masjid telah didirikan di Indonesia, di Medan ditemukan sejumlah masjid yang didirikan dan dikelola komunitas Salafi, seperti Masjid Mukhlishin di Jalan Karya Jaya, Masjid Abu Bakar ash-Shiddiq Sei Mencirim, Masjid di gang Wakaf Medan Denai, dan lainnya.

Selain daripada itu, sejumlah yayasan muncul untuk mewadahi gerakan dakwah Salafi. 7 Jumlah itu sangat banyak sekali dan sukar untuk menginventarisasinya kecuali dengan melakukan sebuah penelitian khusus untuk ini. Sebagian kecil dapat disebutkan seperti Minhaj as-Sunnah Bogor, Minhajus Sunnah Medan, Ihya' as-Sunnah, Sabilur Rasyad (Medan). Ditemuka juga yayasan yang berorientasi Salaf atau menisbatkan diri kepadanya seperti Wahdah Islamiyyah yang berdirinya didanai oleh Jam 'iyyah Ihya' alTuras al-Islamy bersama al-Haramain, dan Jam 'iyyah Dar al-Birr (Abu Mujahid, 2012, p. 194), selain itu dikenal pula asy-Syifa', Yayasan Imam al-Bukhari, al-Safwa (AshShafwah), Ibadrurrahman, Mutafaqqun 'Alaih, ar-Rayyan, dan lain sebagainya. 
Untuk mendukung dakwah Salafi, jamaah juga mendirikan stasiun radio dan TV, di antaranya adalah TV Rodja, radio Rodja (Bogor), radio Hang di Batam, radio arRayyan di Geresik, dan sejumlah radio lainnya. Selain TV dan Radio, majalah juga diterbitkan, di antaranya Majalah as-Sunnah, Majalah Salafy, Majalah al-Fatawa, Majalah al-Furqan, Majalah Qiblati, Majlah El-Fatah, Sakinah, dan lainnya.

Dari seluruh media yang ada, maka penerbitan buku menjadi fenomena yang mencengangkan. Ribuan karya ulama Salafi telah diterbitkan dari hasil tulisan ustadz Indonesia dan terjemah dari ulama Timur Tengah, baik kontemporer maupun klasik. Karya-karya itu membajiri toko-toko buku di Nusantara dan dibaca jutaan penduduk Indonesia. Karena itu, tidak asing lagi bagi kaum Muslim melihat tata cara shalat yang bersedekap di dada ketika berdiri, merapatkan kaki ketika sujud, dan ibadah-ibadah lainnya yang selama ini asing di Nusantara.

\section{Sejarah Awal Salafi Masuk ke Sumatera Utara}

Medan dijadikan pusat gerakan dakwah Salafi di wilayah Sumatera Utara. Gerakan dakwah mereka tidak muncul begitu saja dan memiliki alur sejarah yang melibatkan tokoh-tokoh Muhammadiyah, Persis, dan NII. Keterlibatan yang dimaksud adalah terkait dengan ide-ide yang mereka suarakan. Sesungguhnya, bukan tokoh-tokoh itu yang melahirkan secara langsung gerakan dakwah Salafi babak ke-3 ini di Sumatera Utara. Ide-ide yang disuarakan sejumlah orang-orang Muhammadiyah dan Persis, seperti kembali kepada Al-Quran dan Sunnah dan memberantas TBC (Tahyul Bidah dan Churafat), menggugah sejumlah orang untuk mewujudkannya dalam kehidupan kaffah. Dakwah Islam Kaffah yang disuarakan pada tahun 1970-an ini mendorong sejumlah kelompok masyarakat mendirikan pendidikan-pendidikan berorientasi Sunnah, seperti Al-Ulum, Ath-Thayyibah, Pinang Lombang, dan lainnya sebagainya. ${ }^{8}$

Pada tataran Islam Kaffah, baik Muhammadiyah maupun Persis dianggap sejumlah orang tidak sepenuhnya telah mewujudkan Islam Kaffah tersebut dalam kehidupan masyarakat, bahkan untuk komunitas mereka sendiri. Orang-orang dari Ormas keagamaan tidak memiliki alur yang sama dalam sejumlah hal, bahkan dalam orientasi dakwah. Sejumlah tokoh - dan ini yang menjadi gejala umum - adalah mereka yang lebih cenderung kepada gerakan pembaharuan Mesir yang dipengaruhi oleh Syaikh Jamaluddin al-Afghani, Muhammad Abduh, dan Rasyid Ridha ketimbang Muhammad ibn Abd al-Wahhab di Arab Saudi. Literatur-literatur yang digunakan lebih banyak dari para pembaharu Mesir itu ketimbang litartur Salafiyah-purifikasi Arab Saudi. ${ }^{9}$ Karena itu, warna ormas-ormas tersebut lebih cenderung pada pembaharuan ketimbang Salafiyyah utuh, yang akhirnya ormas tersebut menjadi corong medernisasi, bahkan sekarang sejumlah tokoh belakangan terlihat menjadi pengusung paham liberalisme.

Dalam korelasi Salafi babak ke-3 ini, peran seorang ustadz yang bernama Jamaluddin di Sumatera Utara tidak dapat diabaikan. Ia termasuk di antara orang yang ingin menerapkan ide-ide Islam secara kaffah dan aplikatif. Ia meninggalkan bangku kuliahnya di IAIN-SU Fakultas Syariah dan melanglang buana mencari para asatiz untuk mengajarkan ilmu Hadits, terutama yang terkait dengan takhrij Hadits. Perjalanan itu membawanya dari Sumatera sampai ke Malaysia dan negara jiran lainnya. Tujuan akhirnya adalah Arab Saudi, namun langkahnya terbatas hanya di sampai 
Thailand. Disebabkan terjadinya kerusuhan di Burma maka ia tidak dapat melanjutkan perjalanan daratnya ke Haramain. Keinginannya untuk mendalami ilmu Hadits disebabkan hasil dialognya dengan seorang ustadz Muhammadiyah yang baru pulang dari Mesir, yaitu Ustadz Ali Yaqub Matondang. Menurutnya, jika ingin memperkecil khilafiyyah maka harus kembali kepada Hadits Nabi SAW. Sekembalinya dari perjalan dari negara-negara jiran ia menuju LIPIA-Jakarta, ingin mendalami hadits kepada Syaikh Mahmud Thahhan, pengarang Musthalah al-Hadis, yang terkenal itu. Namun, Syaikh tersebut telah kembali ke negara asalnya di Timur Tengah, maka keinginanya untuk talaqqi tidak terwujud.

Di Sumatera Utara, Ustadz Jamaluddin telah berjibaku untuk mendirikan sebuah pesantren sederhana, ia berhasil mendapatkan lahan di Talun Kenas dan mendidik para santrinya di pesantren ini. Sesungguhnya, saat itu ia belum memahami manhaj Salaf sebagaimana yang diusung oleh Salafiyah. Perkenalannya dengan manhaj ini baru setelah ia membawa para santrinya untuk melanjutkan studinya ke pesantren Salafi di Jawa yang dikelola oleh Ja'far Umar Thalib (waktu itu masih di Arab Saudi mencari bantuan), Abdul Qadir Jawas, Abu Nida', dan lainnya. Selain itu, ia juga mendengarkan istilah Salafi muncul dari sejumlah orang-orang yang baru pulang dari Afganistan, seperti Ustadz Abul Fatah. Sebenarnya, murid-murid yang dibawanya ke Pesantren Ja'far Umar Thalib itu adalah generasi keempat dari hasil didikannya di Talun Kenas. Mereka adalah Abdul Mu'thi, Faisal Jamil, 'Ali 'Ishmah, satu dari mereka yaitu Ustadz Abdul Mu'thi melanjutkan studinya ke Yaman. Dua dari murid ini kembali ke Medan dan mengajar di daerah ini. Ustadz Faisal Jamil memusatkan dakwahnya di Gang Wakaf, Denai, dan Ustadz Abu Umair di Brayan.

Selain Ustadz Jamaluddin dan Ustadz Abul Fatah, dikenal juga sejumlah Ustadz yang mengasaskan dakwah Salafiyah di wilayah ini, yaitu Ustadz Abu 'Umar Basyir, ia telah menyebarkan dakwah Salafi sejak tahun 1991 hingga tahun 1997 setelah kembalinya dari Arab Saudi. Selain itu, yang banyak berperan saat ini adalah Ustadz Abu Ihsan al-Astari dan Ustadz Ali Nur. Mereka menjadi dai aktif di Medan setelah menamatkan studinya di Pakistan. Kedua tokoh ini, pada awalnya adalah orang-orang yang dikirim untuk berjihad di Afganistan, yaitu pada tahun 1990 dan disusul tahun berikutnya oleh Ustadz Ali Nur. Namun karena perjumpaan mereka dengan syaikhsyaikh Salafi, akhirnya menghantarkan mereka belajar Islam di Pakistan, yaitu di Jami'ah al-'Ulum al-Astariyyah, dan al-Jami'ah al-Islamiyyah. Di sinilah mereka bersentuhan dengan paham Salaf.

Untuk memudahkan dakwah, Abu Ihsan al-Astari dan kawan-kawannya mendirikan Yayasan Minhajus Sunnah Medan dan Mendirikan Masjid al-Mukhlisin. Sebelumnya, dakwah mereka terpusat di Masjid Muslimin, jalan Sun Yat Sen. Sekarang, selain di Masjid Mukhlisin, dakwah mereka juga secara rutin dilakukan setiap hari Minggu di Masjid Ulul Albab, jalan Sutomo Ujung, IAIN-Medan. Sementara itu, Ustadz Ali Nur memusatkan dakwahnya di Masjid Abu Bakar ash-Shiddiq dan juga mendirikan sekolah Dasar di Sei Mencirim. Di Masjid Abu Bakar ash-Shiddiq ini juga dipusatkan sekretariat yayasan Sabilur Rasyad. ${ }^{10}$

Selain tokoh-tokoh yang disebutkan di atas, ditemukan pula sejumlah Ustadz yang berkontribusi menyuarakan paham Salafi namun tidak menekankan penyebutan ini untuk komunitas mereka. Misalnya, Yayasan asy-Syifa' (Ustadz Khumaidi dan 
Shafwani) yang pengajiannya berpusat di Masjid Taqwa Polonia, Medan, Pesantren Ibadurrahman di Langkat (Ustadz Azmi Syahid), Yayasan Mutafaqqun 'Alaih, Yayasan ar-Rayyan, dan lainnya.

Selain para tokoh dan yayasan yang disebutkan sebelumnya, peran Ma'had asSunnah di Tanjung Morawa tidak dapat diabaikan. Ma'had ini telah melahirkan para santri yang telah diterjunkan di wilayah Sumatera Utara. Tidak hanya sampai di sini, bekerja sama dengan pengurus Masjid Muslimin, yaitu Abdur Rahim, seorang keturunan Arab dari kabilah al-Amri, mereka selalu melakukan daurah dan kajian dengan menghadirkan pembicara dari Arab Saudi, misalnya Syaikh Dr. Nayeef, Syaikh Sulaiman, Syaikh Dr. Heesyam, Syaikh Mamduh Farhan al-Buhairi (Musyrif Internasional Majalah Qiblati), Syaikh Prof. Dr. Muhammad al-Abdan, Syaikh Dr. Bandar, Syaikh Fahd Ibrahim al-Fu'aim (editor tulisan Shalih Fauzan), Syaikh Khalid alMatrudi, Syaikh Ali Shalih dan Syaikh Usman Shalih. Syaikh Usman Shalih aktif memberikan kajian pada malam Rabu Malam ke-1, 2, dan 5 di Masjid Muslimin.

\section{Sejarah Berdirinya Yayasan Minhaj As-Sunnah Medan}

Yayasan Minhajus Sunnah adalah wadah jamaah Salafiyyah di Sumatera Utara untuk berkumpul menjalankan dakwah. Salah satu turunan dari yayasan ini adalah sekolah Ulun Nuha. Sekolah ini berlandaskan pada asas-asas nilai Islam yang diterapkan, baik dalam pembelajaran maupun kehidupan sehari-hari. Landasan utamanya adalah AlQuran dan Sunnah Rasulullah SAW. Yayasan Minhajus Sunnah berusaha untuk berperan aktif dalam mendidik dan membina putra dan putri bangsa untuk menjadi insan yang memiliki pondasi keimanan yang kokoh kepada Allah SWT, berpemahaman agama yang lurus, berakhlak al-karimah, cakap, kreatif, inovatif, mandiri, berpengetahuan yang tinggi, serta bertanggungjawab.

Menurut Bapak Misbah Sahuri (Konsultan bidang Pendidikan dan Manajemen Yayasan Minhaj Assunnah Medan) mengatakan, sejarah lahirnya Yayasan Minhajus Sunnah Medan; masyarakat Jalan Karya Jaya Gang Ekawali Pribadi Medan Johor Medan menginginkan supaya di daerah ini didirikan model pendidikan yang berbeda dengan sekolah-sekolah yang telah ada baik dari segi kurikulum maupun dari penampilan fisik. Sehingga pada tanggal 7 Mei 2005 dengan akta notaris Hj. Jasmin Rivai SH didirikanlah Yayasan Minhajus Sunnah di awali berdirinya Ulun Nuha tingkat SLTP disusul Tingkat SMAkemudian SD dan TK. Pada tanggal 26 Oktober 2017 terjadi perubahan pengurus. ${ }^{11}$

Sedangkan menurut Ustadz Ahmad Pinta Tarigan LC, Ustadz M. Fachyuzar, S.Pd (Kepala Sekolah SMP, SMA Yayasan Minhaj Assunnsh Medan); SMP berdiri tahun 2009 dan SMA tahun 2013. Menurut kedua Ustadz tersebut yayasan ini berbeda dengan sekolah yang ada disekitar Kecamatan Medan Johor, ini program unggulannya adalah Tahfiz Alquran, kurikulumnya selain kurikulum SKB 3 Menteri juga kurikulum disadur dari kurikulum Arab Saudi, dan ciri khas yang lain pemisahan ruang kelas laki-laki dan perempuan. Di sekolah ini guru-gurunya yang bapak-bapak secara penampilan memakai jenggot, baju panjang dan celana gantung (cingkrang), sedangkan ibu gurunya memakai cadar yang dianggap negatif oleh masyarakat. Seiring dengan berjalannya waktu anggapan masyarakat yang negatif berubah menjadi positif, sekarang banyak orang tua wali murid yang mendaftarkan anak-anaknya ke yayasan ini. ${ }^{12}$ 
Perkembangan Yayasan Minhajus Sunnah, menurut Ustadz Ahmad Pinta Tarigan LC, Ustadz M. Fachyuzar, S.Pd (Kepala Sekolah SMP, SMA Yayasan Minhaj Assunnah Medan). Sebagaimana sudah diterangkan bahwa Yayasan Minhaj Assunnah pertama sekali didirikan adalah sekolah tingkat SMP tahun 2009 dan tingkat SLTA/SMA berdiri tahun 2013, pada tahun yang sama didirikan sekolah TK dan SD. Menurut Bapak Irwansyah Saragih (Ketua Yayasan Minhaj Assunnah) yang mendaftar ke Yayasan Minhaj Assunnah untuk Tahun Ajaran 2017/2018 melebihi kapasitas, sehingga banyak calon siswa/siswa baik tingkat SD, SMP dan SLTA yang tidak bisa diterima karena kekurangan kelas. ${ }^{13}$

Visi Sekolah Ulun Nuha adalah membina generasi Islam yang berilmu, beriman dan berakhlak mulia akhlak al-karimah serta mampu menghadapi era globalisasi di atas manhaj Ahlus Sunnah Waljama'ah. Misalnya menghasilkan lulusan yang memiliki keimanan yang kokoh kepada Allah SWT, pemahaman agama yang lurus, akhlak yang mulia, cakap, mandiri, kreatif, inoavtif, berpengetahuan yang tinggi, dan bertanggungjawab di atas Manhaj Ahlus Sunnah Waljama'ah

Menurut Bapak Irwansyah Putra SE (Ketua Yayasan Minhaj Assunah Medan) pengangkatan atau suksesi kepengurusan dilakukan dengan bermusyawarahnya pimpinan-pimpinan utama dari yayasan ini yang dianggap 'alim, setelah itu divoting atau diputuskan siapa yang dijadikan sebagai ketua, sekretaris, bendahara dan bidangbidang lainnya. Dtambahkan Pak Irwansyah; suksesi kepengurusan yang ideal di dalam Islam adalah mengikuti Sunnah Khulafa' ar-Rasyidin, yaitu bisa dilakukan dengan musyawarah, penetapan dengan washiyat, dan pembentukan tim formatur. ${ }^{14}$

Menurut Bapak Irwansyah Putra SE (Ketua Yayasan Minhaj Assunah Medan), standar khusus untuk diangkat menjadi calon ketua adalah Assabiqun al-Awwalun (generasi awal dari yayasan), beribadah Aswaja (Ahli Sunnah wa al-Jamaah), komunikasi baik, ekonomi lebih mapan, aksesibilitas dan mudah berhubungan komunikasi di antara antara pengurus. ${ }^{15}$

\section{Kedudukan Teologi Islam dalam Ajaran Salafiyah Yayasan Minhaj As-Sunnah}

Pada awalnya, terma teologi tidak dikenal di dalam Islam, namun belakangan kata ini dipergunakan oleh sebagian penulis untuk menjelaskan kepercayaan kaum Muslim. Oleh sebab itu, istilah ini adalah kata pinjaman yang digunakan dalam kajian Islam. Jika dirujuk dalam kesejarahannya, maka istilah teologi ditemukan berasal dari Bahasa Yunani. Kata ini merupakan gabungan dua kata "theos", dan "logos". Arti dasarnya adalah suatu catatan atau wacana tentang Tuhan. Dengan demikian teologi adalah seperangkat penjelasan yang dikemukakan yang berhubungan dengan ketuhanan.

Oleh Zurkani Jahja teologi dijelaskan sebagai kajian tentang Tuhan yang di dalam Islam disebut dengan teologi Islam (Ferguson, Wright, \& Packer, 1988, pp. 680681; Jahja, 1996, p. 5). Sebagian mereduksi kata teologi hanya pada batas keyakinan. Karena itu, teologi Islam adalah semakna dengan Ushuluddin, yaitu tentang dasar-dasar agama Islam. Namun demikian, ditemukan juga yang memaknainya lebih dari sekedar masalah keyakinan. Dalam kajian ini istilah teologis dirumuskan sebagai pengetahuan tentang Tuhan dan objek-objek kepercayaan lainnya seperti ibadah dan muamalah yang dalam hal ini dilihat dari perspektif Islam. Kendatipun demikian, aksentuasi tetap pada masalah keyakinan dalam Islam. 
Jika teologi dipahami sebagai pengetahuan tentang Tuhan yang mencakup objek-objek kepercayaan dalam Islam, maka teologi identik dengan makna syariah secara umum. Sebab syariah mencakup segala sesuatu yang berhubungan dengan Islam, baik itu tentang keyakinan maupun realisasi dari keyakinan itu, yaitu amal-amal keimanan dan ekspresi keyakinan dalam tingkah laku. Namun, jika syariah dipahami secara khusus, maka ia hanya mencakup tentang urusan amaliyah semata, tidak meliputi ajaran tentang akidah atau keyakinan dan akhlak. Dari perspektif inilah ajaran Islam dibagi ke dalam tiga cakupan besar, yaitu akidah, syariah, dan akhlak. Akidah dikhususkan pada aspek keyakinan dan keimanan. Sementara itu, syariah mengembil bentuk pada aspek amaliyah, seperti ibadah (misalnya shalat, puasa, haji, dan lainnya), mu'amalah, (baik iqtishadiyyah seperti jual beli, gadai, dan lainnya, maupun ghair iqtishadiyyah seperti munakahah, hibah, kewarisan, sedekah, dan lainnya), dan siyasah (misalnya ajaran tentang suksesi pemerintahan). Adapun akhlak merupakan ajaran tentang adab dan tingkah laku yang distandar sebagai kebaikan atau yang ditengarai berada diluar standar kebaikan tersebut. Atas dasar inilah akhlak selalu dihubungkan dengan aspek mistisisme dalam Islam atau disebut juga tasawuf.

Kelihatannya, Yayasan Minhaj as-Sunnah tidak memiliki pedoman khusus yang ditulis atau diterbitkan secara mandiri oleh Yayasan ini dalam masalah kategorisasi ajaran Islam ke dalam tiga bagian besar di atas. Namun, ini dapat dipahami bahwa kajian-kajian tentang keislaman dipahami secara umum oleh sebagian Ustadz di Minhaj as-Sunnah sebagai bagian integral dari ajaran Islam yang tidak dapat dipisahkan. Dengan kata lain, Islam harus dipahami secara kaffah tanpa dikotomi dan parsialitas. Walau demikian, kategorisasi ini tidak diklasifikasikan sebagai bid'ah yang terlarang. Sebab hal ini berbicara tentang tunjukan dari ajaran Islam itu sendiri yang menginisiasi diri ke dalam cakupan tersebut. Sama halnya pembagian terhadap tauhid di dalam ajaran Salafiyah kepada rububiyyah, uluhiyyah, dan asma ' wa shifat.

Jika pembagian ajaran itu ditujukan untuk mengkotak-kotak ajaran Islam tanpa adanya korelasi dan kesatuan ajaran atau tercerabut dari ajaran lainnya, maka pemahaman seperti ini tentu ditolak. Karena itulah salafi Minhaj as-Sunnah tidak membagi ajaran Islam ke dalam ajaran kulit (syariat) dan ajaran inti (batin atau hakikat) yang ditengarai untuk mendikotomi dan memparsialisasi ajaran Islam. Sebab, dalam pemahaman Salafiyah bahwa semua ajaran Islam itu adalah bagian dari kesatuan ajaran Islam yang kaffah.

Yayasan Minhaj as-Sunnah sangat terbuka terhadap kajian-kajian di luar karyakarya Salafiyah, termasuk dalam pembahasan ini. Prinsipnya adalah setiap pendapat yang sesuai dengan kebenaran merupakan ajaran kebenaran yang harus dipertimbangkan. Standarnya adalah Al-Quran dan Sunnah dengan paradigma (manhaj) Salaf as-Shalih. Salah satu dari contoh kasus adalah ditemukannya Ustadz Salafiyah yang mengitip karya-karya ulama Asy'ariyah baik dalam akidah, ibadah, hadits, muamalah, dan lainnya. Dalam kasus ini misalnya, ditemukan penukilan terhadap karya al-Izz Ibn Abd as-Salam dari ulama Asy'ariyah. Ulama ini mengkritisi pembagian ajaran Islam ke dalam ajaran kulit (syariat) dan ajaran inti (hakikat).

Menurut pandangan umum Salafiyah di Nusantara bahwa di Indonesia telah dijalankan sebagian besar Syariat Allah. Namun kaum Muslim perlu terus untuk berikhtiyar secara syari'i agar hukum Allah dapat tegak dinegeri ini secara kesuluruhan. 
Di antara hukum Allah yang telah tegak di wilayah ini dapat dilihat seperti shalat, infaq, sadaqah, zakat, puasa, haji, membangun masjid, makanan halal, masalah pernikahan, kewarisan, dan lainnya. Kendatipun hukum syariah belum tegak secara utuh, bukan berarti hukum syari'at yang telah ditegakkan itu batal dan tidak diterima Allah Azza wa Jalla. Sebaliknya, bagi orang yang sengaja meninggalkannya bukan berarti tidak berdosa. Namun demikian, hal itu tidak membuat pelakunya keluar dari Islam selama ada azam yang kuat serta upaya untuk menjalankan syari'at itu secara utuh. Karena itu, Salafiyah berpandangan bahwa kondisi dan kemampuan merupakan pertimbangan hukum yang harus dipahami. Secara spesifik, dalam penegakan hukum Hudud,maka orang yang berkewajiban menjalankannya adalah penguasa, adapun rakyat dan Ulama hanya sebatas memberikan masukan dan nasehat dengan cara baik. Ketidaktegaknya hudud tidak dapat dijadikan alasan untuk membangkang kepada penguasa apalagi sampai berupaya untuk menumbangakan dan mengkudeta kekuasaan yang sah.

Dalam pada itu, Salafiyah berpandangan bahwa Allah Azza wa Jalla melarang manusia ragu dalam menjalankan hukum-Nya. Kebenaran hukum Allah itu telah dibuktikan secara kauni dalam lintas sejarah, bahwa para Ahli kitab sekalipun, sebagaimana firman Allah Azza wa Jalla dalam surah al-An'am ayat 114 dan az-Zumar ayat 55 .

Berdasarkan penjelasan di atas, dalam pandangan Salafiyah, tidak ada hukum yang lebih baik dari syariat Allah. Karena itulah setiap kaum muslim wajib mengamalkan dan memperjuangkan agar hukum Allah tegak di muka bumi. Namun dalam hal menegakkannya haruslah dengan pedoman syariah dan melihat mashlahat dan mafsadatnya. Atas dasar inilah maka tidak boleh menegakkan syariah dengan menentang dan melanggar syariah itu sendiri. Demikian pula mendakwahkannya, maka harus dengan cara-cara yang syar' $i$, tidak tergesa-gesa, dan penuh dengan kesabaran dan tanggungjawab. Dengan demikian, sebagaimana dikatakan di dalam penelitian Siti Tienti W. Nasution terhadap komunitas Salafiyah, ia menemukan bahwa dakwah Salafiyah tidak mengarahkan untuk bentrok (secara frontal) dengan para penguasa dan undang-undang yang berlaku karena dakwah ini menginginkan perbaikan dan bersungguh-sungguh dalam memperbaiki keadaan. Mereka berpendapat bahwa hukum dan penguasa bukanlah tujuan tetapi hal itu adalah wasilah (sarana) untuk beribadah kepada Allah semata dan agar agama ini menjadi milik Allah seluruhnya. Bentrok dengan penguasa atau melakukan kudeta dapat mengakibatkan urusan yang lebih besar. Demikian juga sesungguhnya peraturan Islam harus mempunyai penopang dan pembelanya.

\section{Pengertian Jihad dan Aplikasinya}

Dalam kamus bahasa Indonesia jihad diberi makna beberapa alternatif. Pertama, jihad diartikan usaha dengan sungguh-sungguh dan segala daya uapaya untuk mencapai kebaikan. Kedua, usaha sungguh-sungguh membela agama Islam dengan mengorbankan harta benda, jiwa dan raga. Ketiga, perang suci melawan orang kafir untuk mempertahankan agama Islam (Amruddin, 2015, p. 9).

Secara bahasa (etimologi), kata jihad berasal dari bahasa Arab, yaitu bentuk masdar yang berasal dari kata jahada, yujahidu, mujahadatan dan jihadan yang artinya bekerja sepenuh hati. Kamus Al-Munjid fi al-Lughah wa al-a'alam lafaz lahada al- 
'aduwwa, artinya qatalahu muhammatan 'aniddin yang artinya menyerang musuh dalam rangka membela agama (Ma'luf, 1986, p. 106).

Secara etimologi para pemikir Islam memberikan pengertian yang berbeda mengenai konsep jihad. Muhammad Chirzin menyebutkan jihad adalah sebagai suatu kewajiban muslim yang berkelanjutan hingga kiamat, tingkat rendah berupa penolakan hati atas keburukan atau kemungkaran dan yang tertinggi barupa penolakan hati atas keburukan atau kemungkaran dan yang tertinggi berupa perang di jalan Allah. Di antara keduanya adalah perjuangan dengan lisan, pena, tangan berupa pernyataan tentang kebenaran di hadapan penguasa yang zalim (Chirzin, 1997, p. 12). M. Quraish Shihab dalam tafsir Al-Misbah menjelaskan makna jihad adalah berjuang dengan harta mereka antara lain dengan memberi bantuan peperangan dan pembelaan agama, dan orangorang yang berjuang memberi tempat kediaman bagi orang-orang yang berhijrah dan membela rasul dan kaum Muhajirin. Di sini terlihat bahwa jihad tidak hanya diartikan perang saja, tetapi memberi pertolongan kaum muslimin yang berhijrah adalah termasuk jihad (Amruddin, 2015, p. 13).

Pengertian jihad yang lebih luas dimaknai untuk menggambarkan perjuangan hidup seseorang dengan mengerjakan kebaikan, memenuhi tanggung jawab terhadap kelurga, membersihkan tempat tinggal, melawan memakai obat-obatan terlarang, atau bekerja untuk kepentingan sosial. Tanpa dilupakan bahwa jihad juga digunakan dalam pengertian peperangan untuk pembebasan dan perlawanan.

Menurut Ustadz Irwansyah dari Minhaj as-Sunnah, jihad tidak sama dengan radikalisme dan terorisme yang menghancurkan peradaban manusia, menimbulkan korban jiwa yang tak bersalah dan meluluhlantahkan fasilitas-fasilitas umum milik masyarakat, termasuk warisan peradaban Islam yang membanggakan umat Islam. Jika pada waktu jihad harus dalam bentuk perang, maka dalam jihadnya tidak boleh mengedepankan hawa nafsu. Demikian juga strategi aksi yang akan digunakan tidak boleh serampangan. Bahkan dalam hadits dijelaskan ketika peperangan terjadi tidak boleh mengganggu orang tua, perempuan yang tidak terlibat dalam peperangan, anakanak bahkan tidak boleh merusak lingkungan. Jihad yang dilaksanakan harus didasari pada kebersihan hati, kebersihan niat, sarana dan tujuan. Jihad tidak boleh menggunakan sarana-sarana yang diharamkan, misalnya pencurian sebagai pendanaan untuk jihad. Jihad dalam bentuk perang dengan senjata hanya berlaku di wilayahwilayah darul harb, bukan wilayah-wilayah aman yang tidak ada gangguan terhadap Islam dan kaum muslimin. Pada wilayah-wilayah aman, Islam memerintahkan umatnya untuk bersungguh-sungguh mengerahkan segala kemampuannya untuk berjihad dengan lisan dan tulisan, berdakwah dengan hikmah, mauizah hasanah dan argumentasi yang baik. ${ }^{16}$

Jihad pada dasarnya memiliki konsep yang lebih komprehensif, salah satu sisinya adalah bertujuan di jalan Allah melalui penggunaan senjata. Namun, jihad dengan pengertian sempit ini oleh Al-Quran dibatasi pada saat-saat tertentu khususnya dalam rangka mempertahankan diri. Karena kebanyakan umat Islam sering memahami dan mengamalkan jihad dalam makna sempit telah mengakibatkan pandangan dunia non muslim sebagai terotis penuh kekerasan dan mengartikan jihad hanya sebagai holy war (perang suci). 
Yayasan Minhaj as-Sunnah memahami adanya elaborasi dalam makna jihad di antaranya:

a) Jihad Membangun Pendidikan

Menurut Bapak Misbah Sahuri (Konsultan pendidikan dan manajemen), Yayasan Minhaj Assunnah terutama mengembangkan jihad dalam dua bidang yaitu bidang pendidikan dan dakwah, melalui media pendidikan sekaligus mengembangkan dakwah Islam. Jihad mengentaskan kebodohan pertama sekali mendirikan sekolah tingkat SMP tahun 2009 dan tingkat SLTA/SMA berdiri tahun 2013, pada tahun yang sama didirikan sekolah TK dan SD. ${ }^{17}$

b) Jihad Membangun Akhlak Umat

Salah satu jihad dalam ranah ini adalah jihad melawan korupsi. Rendahnya saknsi terhadap para koruptor merupakan indikasi meluasnya suap, kurangnya hukuman bagi koruptor dan abainya institusi publik merenspon kebutuhan warga negara untuk terciptanya pemerintah yang bersih. Dengan semangat jihad dari para da'i para hakim dan aparat penegak hukum lainnya sudah seharusnya didukung untuk berani menghukum mati sesuai koridor hukum. Apalagi beberapa kalangan selama ini malah telah membuat pernyataan agar para koruptor itu dihukum mati saja demikian pendapat Ustadz Misbah Sahuri ${ }^{18}$

\section{c) Jihad Mempersatukan Umat}

Menurut Ustadz Irwansyah, seharusnya kita terus mendorong umat Islam memiliki kesadaran yang mendalam untuk mengamalkan ajaran agamanya sebagaimana yang dijelaskan dalam surat al-Hujarat bahwa kita harus berhati-hati dalam mengakses informasi. Seperti, kita dapatkan pada zaman sekarang orang mudah sekali membuat isu dan hal-hal provokatif. Kalau tidak berhati-hati dan cermat umat Islam bisa berbenturan satu sama lain. Menurut Ustadz Irwanyah, jadikanlah perbedaan sebagai media untuk saling mengkaji ajaran yang benar dengan menghargai dan bertoleransi. Irwansyah juga memesankan, antar organisasi atau kelompok harus menjalin komunikasi yang baik, jangan sampai ketika ada masalah langsung memberikan vonis. Dahulukan komunikasi, jangan memberikan vonis-vonis. kita berharap tidak lagi muncul sikap-sikap eksklusif dan arogan. ${ }^{19}$

\section{d) Jihad Membangun Politik Umat Islam}

Mengkritik realita politik saat ini yang didominasi oleh politik sekuler yang jauh dari nilai-nilai Islam dan cenderung menghalalkan segala cara. Sekuler yang dimaksudkan di sini adalah ketika tidak semua tindakannya dalam bernegara dan berpolitik diikat dengan nilai-nilai agama. Oleh karena itu umat Islam mesti mengubah kondisi politik yang tidak sesuai dengan aturan umat Islam. Usaha-usaha untuk mengubah kondisi tersebut dapat digolongkan ke dalam amal jihad. Apabila umat Islam tidak sanggup untuk mengubah sistem yang ada di negara non muslim, maka yang perlu dilakukan adalah mengubah manusianya dengan dakwah dan pendidikan. Hal ini dapat dicontohkan seperti yang pernah dilakukan oleh Rasulullah Muhammad SAW dalam membangun manusia dengan membebaskan dari kemusyrikan, hawa nafsu, dan jahiliyah. Rasulullah Muhammad SAW menanamkan aqidah tauhid pada masyarakatnya, penguatan keimanan dengan pengertian yang sebenarnya dan kemuliaan akhlak dalam kehidupan masyarakat serta menyucikan dirinya dari 
pemikiran sesat. Berdasarkan usaha-usaha ini Rasulullah telah mampu mendidik generasi teladan yang pertama generasi yang mampu mendirikan Daulah Islamiyah. ${ }^{20}$

e) Jihad Sosial

Ajaran Islam memiliki ajaran yang mengarah kepada perubahan, yaitu terus berusaha ke arah yang lebih baik.

f) Jihad Membangun Ekonomi

Membicarakan pembangunan umat Islam tidak mungkin melupakan pembangunan dalam bidang ekonomi. Kekuatan eknomi dari satu keluarga dan masyarakat akan dapat menghindarkan umat Islam dari kekufuran. Karena itu seyogyanya kaum muslim kembali kepada sistem syariah dalam membangun ekonominya. Sebab, sistem ribawi akan mendatangkan malapetaka bagi umat Islam.

g) Jihad Memperkuat Dakwah

Pada zaman modern ini, perang pikiran dan psikologis, ekonomi dan politik tampaknya lebih jitu dan berdampak lebih jauh serta lebih dalam dengan mass media sebagai sarana dakwah. Karena itu, peran dakwah dari berbagai media merupakan suatu keniscayaan.

\section{Sebab Terjadinya Radikal-Terorisme Menurut Salafisme}

Sejumlah penulis Salafi menilai, penyimpangan yang dilakukan terorisme saat ini disebabkan banyak faktor, di antaranya yaitu:

a) Paham Takfiry

Salah satu yang menonjol dari kemunculan radikal-terorisme adalah faktor paradigma yang mereka bangun dalam merespon keadaan umat Islam yang sedang terpuruk. Hal ini juga menjadi kesadaran Salafi Minhaj as-Sunnah. Kemunculan radikal tersebut menurut yayasan ini salah satunya disebabkan oleh respon terhadap carut marut perpolitikan dan situasi kontemporer umat Islam. Para terorisme mengatakan bahwa saat ini adalah era Jahiliyah disebabkan telah runtuhnya khilafah Islamiyah di Turki sebagaimana yang pernah dikatakan Imam Samudra. Menurut Salafi Minhaj asSunnah Jahiliyah mutlak tidak lagi ada setelah Rasulullah SAW diutus kepada manusia. Sebab, pada setiap generasi semenjak Rasulullah SAW diutus niscaya ada sekolompok manusia yang terus menerus menampakkan agama Allah.

b) Tidak Mematuhi Ulama Muktabar

Di antara karakter lain yang ditampilkan kelompok radikal terorisme adalah tidak mematuhi nasehat ulama. Mereka melecehkan ulama dan menganggap diri-diri mereka lebih tinggi dari para ulama. Karena itu, tidak ada kriteria yang baku bagi mereka terhadap ulama kecuali sesuai dengan paham radikal yang mereka anut dan mendukung kerusakan yang mereka lakukan. Di dalam sejarah awal kaum Muslim, kelompok seperti ini pernah muncul dan dikenal dengan sebutan Khawarij.

c) Paradigma dan Manhaj Keagamaan

Salah satu yang terpenting dari penyimpangan kelompok radikal terorisme adalah paradigma dan manhaj mereka yang rancu dan keliru. Kekeliruan mereka di antaranya adalah mereka menisbatkan diri sebagai salafiyah tetapi perilaku mereka justru bertentangan dengan salaf. Dengan paham yang keliru itulah mereka menjalankan agama dan merespons keberadaan kaum Muslim. 


\section{Pemahaman Yayasan Minhaj as-Sunnah dalam Memahami Ajaran-ajaran Potensial Radikal-Terorisme}

Yayasan Minhaj as-Sunnah bukanlah sebuah kelompok yang paham keagamaannya diciptakan sendiri oleh kelompok ini. Mereka adalah orang-orang yang bersemangat untuk mengamalkan Islam secara kaffah dengan mengikuti petunjuk AlQuran dan Sunnah sesuai dengan manhaj para Salaf ash-Shalih. Oleh karena itu, yayasan ini menjadikan ulama-ulama Salaf sebagai rujukan dalam setiap sisi dan dimensi kehidupan mereka. Dalam kaitan metode dalam memahami ajaran potensi radikalisme tidak ditemukan metode tersendiri yang dikeluarkan Yayasan Munhaj asSunnah, mereka lebih banyak menyerahkan masalah ini kepada para ulama atau kibar ulama', tidak terkecuali MUI yang berkompoten di Indonesia untuk menjelaskan masalah ini. Namun demikian, dalam dasar-dasar pemahaman umum, ada beberapa prinsip Salafisme memahami ajaran Islam:

a) Prinsip yang Berkaitan dengan Aqidah:

1) Aqidah yang benar adalah aqidah yang diasaskan pada Al-Quran dan Sunnah atau hadits sesuai dengan manhaj sahabat (murid Rasulullah SAW.), tabiin, dan para pengikut jalan mereka (salaf al-ummah). Sebab merekalah yang mendapat garansi dalam hal ini untuk diikuti. Merekalah Salafal-Ummah yang diikut Ahlus Sunnah wal Jamaah.

2) Tauhid mencakup tauhid rububiyah, uluhiyah, asma' wa ash-shifah dan halhal yang terkait dengannya. Memahami sifat-sifat Allah harus sesuai dengan pemahaman generasi awal, yaitu tidak melakukan tahrif (penyimpangan dari zhahir nash), ta'thil (pembatalan atau penafian sifat-sifat Allah), takyif (visualisasi, penggambaran sifat-sifat Allah), tamtsil (menyerupakan sifatsifat Allah dengan sifat-sifat makhluk-Nya), dan tafwidh (penyerahan secara mutlak), tafwidh hanya pada al-kaif (cara dan keadaan).

b) Prinsip yang Berkaitan dengan Ibadah:

1) Melakukan suatu amal ibadah harus didasari ilmu tentang amalan tersebut.

2) Tidak melakukan amal ibadah kecuali ada landasannya dari Al-Quran, Hadits, dan prinsip-prinsip keduanya.

3) Beramal haruslah ittiba' (mengikut atau mencontoh) Nabi Muhammad SAW.

4) Ibadah baru diterima apabila memenuhi dua unsur, yaitu ittiba' (sebagaimana yang telah disebutkan) dan ikhlas (semata-mata karena Allah). Ibadah dan pahala yang diperoleh seorang hamba tidaklah memasukkannya ke dalam surga, namun rahmah Allah-lah yang mengahantarkan manusia masuk ke dalam surga. Oleh sebab itu, ibadah yang sedikit namun dilakukan dengan ikhlas dan sesuai dengan Sunnah Rasulullah SAW tidak bisa dibandingkan kebaikannya dari ibadah yang banyak tetapi menyelisihi Sunnah (kendatipun ikhlas). Sebab, ibadah yang diamalkan manusia untuk menyembah Allah adalah dalam rangka mencari rahmah dan ridha Allah. Rahmah dan ridha-Nya ada di dalam kepengikutan seseorang kepada syariatNya.

c) Prinsip Dasar Siyasah

Islam tidak mengenal sekularisme. Dengan kata lain Islam tidak memisahkan ajaran agama dan urusan mengatur kemashlahatan manusia. Dalam kaitan ini perlu dipahami sebagai berikut: 
1) Siyasah (politik), bukanlah tujuan manusia tetapi sebagai alat untuk menerapkan syariat dan kemashlahatan manusia.

2) Siyasah merupakan amanah dan sarana untuk beribadah kepada Allah dan berbuat baik kepada makhluk-Nya.

3) Undang-undang yang diterapkan untuk mengatur negara dan umat harus mengacu kepada Al-Quran dan Sunnah dan prinsip-prinsip dasarnya.

4) Musyawarah adalah salah satu media di dalam politik Islam. Namun musyawarah yang dilakukan adalah untuk mewujudkan agar diterapkan prinsip-prinsip dari tunjukan Al-Quran dan Sunnah demi mewujudkan tujuan hidup hamba untuk beribadah kepada Allah dan demi kemashlahatan manusia. Oleh sebab itu, tidak diakui musyawarah untuk menentang atau bertentangan dengan kedua sumber itu.

5) Rakyat harus tunduk kepada perintah imam (pemerintah) dan haram menentangnya. Ketundukan itu apabila tidak untuk melakukan kemaksiatan yang sudah jelas kemaksiatannya dilihat dari dalil dan keterangan ulama arrasikhun fi al-ilm.

6) Memberontak terhadap pemerintah kaum muslim hukumnya haram dan pelakunya dikenakan hukuman hudud (bughah).

7) Perintah untuk berperang (jihad) dan berdamai haruslah berdasarkan ketetapan imam (pemerintah). Oleh sebab itu, setiap kelompok yang memerangi kelompok lain tanpa instruksi imam (pemerintah yang sah) maka ditetapkan sebagai kriminal. Pelakunya tidak dikatakan melakukan jihad syar'i. Ini terkait dengan jihad thalab, namun berbeda dengan jihad difa' tidak perlu terlebih dahulu menunggu instruksi imam. Jihad difa' adalah jihad untuk mempertahankan diri dari serangan musuh.

8) Suksesi pemerintahan ideal di dalam Islam adalah mengikuti Sunnah Khulafa' ar-Rasyidin, yaitu bisa dilakukan dengan musyawarah, penetapan dengan washiyat, dan pembentukan tim formatur, atau diangkat dan ditunjuk dalam keadaan genting.

9) Ketika mayoritas kaum muslim mengakui kekuasaan sebuah pemerintahan, maka itulah imam yang wajib diikuti. Kelompok minoritas yang mengangkat imamnya sendiri harus rujuk ke dalam jamaah mayoritas kaum muslim. Jika tidak, maka mereka tergolong melakukan kemaksiatan.

Kaum Muslim tidak boleh memerangi (menyakiti) kelompok non-muslim (dzimmi), musta'min (yang meminta suaka politik), dan mu'ahid (penduduk negara asing yang melakukan perjanjian damai dengan kaum muslim atau tidak memerangi kaum muslim).

\section{PENUTUP}

Dari hasil penelitian ditemukan bahwa Manhaj Salaf merupakan kerangka berpikir atau metodologi penafsiran teks Al-Quran dan Sunnah yang disusun para Salaf untuk membentengi Islam dari penafsiran-penafsiran keliru dan menyesatkan yang didasari oleh kepentingan hawa nafsu. Juga Salaf As-Shalih bertujuan menjaga kemurnian pemahaman teks-teks Islam sebagaimana dikehendaki sang pemilik teks itu yaitu Allah SWT dan Rasulullah SAW. 
Minhaj as-Sunnah menginisiasi diri sebagai kelompok yang menggunakan manhaj Salaf sebagai dasar pemahaman mereka. Hal yang melatarbelakangi Yayasan Minhaj As-Sunnah menjadikan Salafiyah sebagai dasar teologis keagamaannya diasaskan pada kesadaran perlunya beragama secara murni sesuai dengan pemahaman generasi awal. Sebab, belakangan ini, ditemukan banyaknnya penyimpangan dalam memahami Islam tidak terkecuali yang mengaku sebagai Salafiyah (pengikut Salaf) tetapi tidak sesuai secara objektif dengan pemahaman generasi Salaf.

Yayasan Minhaj As-Sunnah memahami bahwa manhaj Salaf atau Salafiyyah tidak memiliki hubungan dengan gerakan dan pemahaman radikal-terorisme. Bahkan dalam manhaj ini ditemukan adanya kemestian kaum muslim untuk bersikap moderat dalam bersikap dan memahami agama, yaitu tidak menjadi picik dan kaku (ifrath) pada satu sisi dan juga tidak menjadi liberal (tafrith) pada sisi yang lain. Dengan demikian, maka yayasan ini menolak paham radikal-terorisme yang muncul saat ini karena tidak sesuai dengan manhaj Salaf.

Yayasan Minhaj As-Sunnah tetap mempertahankan teologis keagamaan Salafiyah di tengah-tengah kecaman berbagai pihak sebagai gerakan radikal-terorisme diasaskan pada kesadaran akan pentingya mengamalkan Islam secara murni dan kaffah dan tidak parsial. Kelompok-kelompok Islam saat ini telah sarat dengan kepentingan duniawi sehingga tidak mampu meninggikan izzah Islam sebagaimana di zaman generasi awal.

\section{REFERENSI}

Abu Mujahid. (2012). Sejarah Salafi di Indonesia. Bandung: Tubagus Publishing.

Amruddin, M. H. (2015). Jihad Membangun Peradaban. Lembaga Studi Agama dan Masyarakat.

Azra, A. (2013). Jaringan Ulama Timur Tengah dan Kepulauan Nusantara Abad XVII E XVIII. Jakarta: Kencana.

Chirzin, M. (1997). Jihad dalam Al-Quran, Telaah Normatif, Historis, dan Prospektif. Yogyakarta: Pustaka Pelajar.

Ferguson, S. B., Wright, D. F., \& Packer, J. L. (1988). New Dictionary of Theology. Illinois: InterVarsity Press.

Hasan, N. (2008). Laskar Jihad, Islam, Militan, dan Pencarian Identitas di Indonesia Pasca Orde Baru. Jakarta: LP3ES.

Jahja, H. M. Z. (1996). Teologi al-Ghazali. Yogyakarta: Pustaka Pelajar.

Ma'luf, A. L. (1986). Al-Munjid Al-Lughah wa al-'Alam. Beirut: Dar al-Wasyriq.

Tholhah, I. (2003). Gerakan Islam Salafiyyah di Indonesia. Jurnal Edukasi, I(JuliSeptember).

Zahir, I. I. (2001). Al-Masya'wa al-Mashadir. Jakarta: Darul Falah. 


\section{CATATAN AKHIR}

${ }^{1}$ https://manhajsalafi.com/teroris-pasti-berakidah-wahabi-termasuk-teroris-bom-thamrin.

${ }^{2}$ http://www.salafynews.com/wahabi-sekte-pembawa-bencana-dan pencipta-teroris.html.

3 Shalih ibn 'Abd al-'Aziz 'Alu asy-Syaikh, Syarh ath-Thahawiyah, p. 408.

4 Ceramah Agama oleh Ustadz Ali Nur di Masjid Dakwah USU Medan, 2016. Isa al-Masih.

${ }^{5}$ Di antara ketergelincirannya adalah pengingkarannya atas kedatangan al-Mahdi dan turunnya

${ }^{6}$ Namun belakangan tokoh ini diklaim para asatiz telah meninggalkan Salafi.

7 Kendatipun di kalangan Salafi sendiri ada pro dan kontra tentang mendirikan yayasan

(Ormas), namun sejumlah masyaikh memperbolehkan menyajikan untuk tujuan memudahkan gerakan dakwah ilallah bukan untuk menciptakan hizbiyyah.

${ }^{8}$ Wawancara dengan Ustadz Jamaluddin pada tanggal 21 Juni 2018.

9 Ibid.

${ }^{10}$ Wawancara dengan Ustadz Ali Nur pada tanggal 22 Juni 2018.

" Wawancara dengan Ustadz Misbah Sahuri (Konsultan Pendidikan dan Manajemen Yayasan Minhaj Assunnah Medan) pada tanggal 6 Agustus 2018.

${ }^{12}$ Wawancara dengan Ustadz Ahmad Pinta Tarigan LC, Ustadz M. Fachyuzar, S.Pd (Kepala Sekolah SMP, SMA Yayasan Minhaj Assunnah Medan) pada tanggal 6 Agustus 2018.

${ }^{13}$ Ibid.

14 Wawancara dengan Ustadz Irwansyah Putra, SE (Ketua Yayasan Minhaj Assunah Medan), pada tanggal 6 Agustus 2018.

${ }^{15}$ Ibid.

${ }^{16}$ Ibid.

${ }_{17}$ Wawancara dengan Ustadz Misbah Sahuri (Konsultan bidang Pendidikan dan Manajemen Yayasan Minhaj Assunnah Medan) pada tanggal 6 Agustus 2018.

${ }^{18}$ Ibid.

19 Wawancara dengan Ustadz Irwansyah Putra, SE (Ketua Yayasan Minhaj Assunah Medan), pada tanggal 6 Agustus 2018.

${ }^{20}$ Wawancara dengan Ustadz Ahmad Pinta Tarigan LC, Ustadz M. Fachyuzar, S.Pd (Kepala Sekolah SMP, SMA Yayasan Minhaj Assunnah Medan) pada tanggal 6 Agustus 2018. 